INTERNATIONAL JOURNAL OF RESEARCHES IN BIOSCIENCES, AGRICULTURE AND TECHNOLOGY

(C) VISHWASHANTI MULTIPURPOSE SOCIETY (Global Peace Multipurpose Society) R. No. MH-659/13(N) www.vmsindia.org

\title{
NUTRIENTS BEHAVIOUR IN LEAVES OF BEARING AND NON-BEARING NAGPUR MANDARIN TREES
}

\author{
College Of Agriculture, Nagpur- (M.S.) India \\ Deptt of Agril. Chemistry and Soil Science \\ Dr. Panjabrao Deshmukh Krishi Vidyapeeth, \\ Akola, Maharashtra- 444104 \\ Sevadal Mahila Mahavidyalaya, Nagpur
}

V.P. BABHULKAR ${ }^{1}$, P.R. KADU ${ }^{2}$, A. P LAMBAT ${ }^{3}$ and P.C.PAGAR ${ }^{4}$

\section{INTRODUCTION:}

Optimum nutritional status in respect of all other essential nutrient elements is required in the citrus plant for maximum of fruits. Aiyappa et.al. (1) Suggested that nutritional requirements of crops could be determined by soil and plant analysis with varying degree of success. Several workers have reported the leaf analysis method being a practical, sensitive and convenient tool to understand the nutritional and fertilizer requirements of fruit trees. Based on leaf analysis method gives an guidelines regarding the minimum and normal nutritional levels of various nutrient elements in plant leaves which govern on overall condition of crops and its growth.

Kanwar et. al. (3) has reported the importance of citrus leaf analysis. However, not much work seems to have been done in nutritional status of Nagpur mandarin. Hence, Studies on nutrient elements composition in citrus leaves of fruit bearing and non-fruit bearing trees of Nagpur mandarin were undertaken at the Regional Fruit Research Station, Katol, Distt. Nagpur, Maharashta State.

\section{MATERIALS AND METHODS:}

The healthy citrus orchards were selected for sampling from different five villages in Katol Tahsil. Approvimately 5-6 months old matured fourth leaf from top of twig was collected from randomly selected fruit bearing and non-fruit bearing citrus pants during Nov. 2005. Hundred leaves from each plant were collected from its four sides. Collected leaf samples were brought in the laboratory at Regional Fruit Research Station, Katol for analysis. All the leaf samples were thoroughly washed with tap water and detergent followed by washing with distilled water. The washed leaves were placed on blotting paper to absorb the moisture and then kept in oven at about stored in $50^{\circ} \mathrm{C}$ temperature and stored in paper bag. The dried leaves of each sample were grinned individually with the use of miser-cum grinder and subjected to the analysis to determine the nutrient elements on AtomicAbsorption Spectrophotometer.

\section{RESULTS AND DISCUSSION:}

Assessment of micronutrient levels presented in Table 1 revealed that in fruit bearing citrus plants of different villages, micronutrient $\mathrm{Cu}$ was observed from 11.7 to $15.6 \mathrm{ppm}$ which is optimum where as in non fruit bearing plants the leaves were 17.3 to 25.9 ppm which is categorized as high as per the Internationally accepted Leaf Nutrient Standards (LNS) reported by Embleton et. al. (2) (Table 2). $\mathrm{Zn}$ content of fruit bearing citrus plants was low i.e. between 18.1 to $23.5 \mathrm{ppm}$ as per LNS and it is optimum in non fruit bearing plant i.e. within Range of 23.5 to $29.1 \mathrm{ppm}$. Fe and $\mathrm{Mn}$ were found optimum in both fruit bearing and non-fruit bearing plant within a range of 107.6 to $120.0 \mathrm{ppm}$ and 45.4 to 55.2 ppm respectively, as compared with the internationally accepted leaf nutrient standards. The carbohydrate was found more in fruit bearing plant as compared with the non fruit bearing plants. This study indicated that carbohydrates played a dominant regulatory role in citrus flowering. Low level of carbohydrates did not induce bud and hence non fruit bearing plants showed lower level than the fruit bearing plants. Srivastava and Singh (4) have suggested the supplementation of carbohydrates in form of starch in 'off year of alternate bearing -which confirms the finding. 
Table 1: Mean value of leaf analysis in respect of micro elements/ carbohydrates in Nagpur mandarin. (ppm on oven dry basis)

\begin{tabular}{|l|l|l|l|l|l|l|l|l|l|c|}
\hline $\begin{array}{c}\text { Sample of } \\
\begin{array}{c}\text { leaves } \\
\text { collected } \\
\text { from }\end{array}\end{array}$ & \multicolumn{3}{|c|}{ Micronutrients in fruit bearing trees } & \multicolumn{3}{c|}{ Micronutrients in fruit non-bearing trees } \\
\cline { 2 - 11 } & $\mathrm{Cu}$ & ZN & Fe & Mn & $\begin{array}{l}\text { Carbohy } \\
\text { derate } \\
\text { g/100g }\end{array}$ & Cu & ZN & Fe & Mn & $\begin{array}{l}\text { Carbohyderate } \\
\text { g/100g }\end{array}$ \\
\hline Katol & 15.6 & 18.1 & 109.2 & 45.4 & 14.61 & 25.9 & 29.1 & 111.6 & 45.6 & 11.02 \\
\hline Sawali & 13.7 & 20.7 & $111 . .0$ & 55.0 & 14.28 & 17.4 & 28.7 & 107.6 & 53.0 & 11.53 \\
\hline Pardi & 11.7 & 21.4 & 108.7 & 54.4 & 14.65 & 20.5 & 26.3 & 111.9 & 55.2 & 12.30 \\
\hline Wandali & 12.3 & 23.1 & 111.0 & 50.0 & 13.82 & 17.3 & 23.5 & 115.3 & 52.6 & 11.84 \\
\hline Dhartwada & 13.3 & 23.5 & 115.9 & 47.9 & 13.53 & 24.4 & 27.4 & 120.0 & 49.5 & 11.79 \\
\hline Mean & 13.3 & 21.4 & 110.5 & 50.5 & 14.18 & 21.1 & 27.0 & 113.8 & 51.2 & 11.70 \\
\hline
\end{tabular}

Table 2: International Leaf Nutrient Standards for citrus :

\begin{tabular}{|c|c|c|c|l|c|}
\hline \multirow{2}{*}{ Element } & \multicolumn{5}{|c|}{ Indices (ppm) } \\
\cline { 2 - 6 } & Deficient & Low & Optimum & High & Excess \\
\hline $\mathrm{Cu}$ & $<3$ & $3-4$ & $5-16$ & $17-20$ & $>20$ \\
\hline $\mathrm{Zn}$ & $<17$ & $18-24$ & $25-100$ & $101-300$ & $>300$ \\
\hline $\mathrm{Fe}$ & $<35$ & $53-59$ & $60-120$ & $121-200$ & $>200$ \\
\hline $\mathrm{Mn}$ & $<17$ & $18-24$ & $25-100$ & $101-300$ & $>300$ \\
\hline
\end{tabular}

\section{Summary:}

Citrus growers of this region facing the problem of alternate bearing or non bearing of fruits. Hence it is thought imperative to study microelement levels of citrus leaves of fruit bearing and non fruit bearing plants by collecting and analyzing leaf samples from various five villages during Nov. 2005 in Katol Tahsil Dist. Nagpur, in fruit bearing plant the micronutrient like $\mathrm{Cu}, \mathrm{Fe}$, and $\mathrm{Mn}$ were found optimum carbohydrates were more and $\mathrm{Zn}$ was low in non fruit bearing plants $\mathrm{Cu}$ was high and $\mathrm{Fe}, \mathrm{Mn}$ and $\mathrm{Zn}$ was optimum where as carbohydrates was found less which might be responsible for fruiting of citrus plants.

\section{References:}

1. Aiyappa, K.M.; K.C. Srivastava and D.P. Muthappa (1976). Studies on the nutritional status of leaves in healthy, high performing productive mandarins orange trees in coorg. Proceeding of the Internatinal Symposium on subtropical and tropical horticulture held in India pp. 578-588.

2. Embleton, T.W.; W.W. Jones, C.K. Labanauskas and W. Reuther. (1973). Leaf analysis as a diagnostic toosl and guide to fertilization in the citrus Industry, Vol.. 3 (Ed. Reuther W.) University of California, pp. 183-201.

3. Kanwar, J.S.; D.R. Dhingra and N.S. Randhwa. (1963) Chemical composition of healthy and chlorotic leaves of citrus plants in the Panjab. India J. Agric. Sci. 33; 268-71.

4. Srivastava, A.K. and Shyam Singh. (1999) Recent trends in citrus production research Souvenir, International Symposium of Citriculture held NRCC Nagpur, pp -174-9. 